\title{
Building an Ethnic Food Ethic: The Case of the Ngigua Indigenous People of Southern Puebla, Mexico
}

\author{
Diosey Ramon Lugo-Morin ${ }^{1}$ (D)
}

Accepted: 6 October 2021 / Published online: 31 October 2021

(c) The Author(s), under exclusive licence to Springer Nature Switzerland AG 2021

\begin{abstract}
Food ethics in the indigenous context is associated with a historical and profound relationship that indigenous groups have with nature. To address this relationship and identify the food uses associated with the maguey plant from a biocultural perspective among the Ngigua indigenous people living in the municipality of Tlacotepec de Benito Juárez in Puebla, the three main communities in the municipality of Tlacotepec de Benito Juárez that make use of the maguey plant were chosen. The study was carried out with a qualitative approach, using a semi-structured interview as a research technique. The analysis carried out recognises the importance of the maguey plant as a biocultural resource for the Ngigua in a context of ethical deliberation. Among the food uses associated with the maguey plant, the following are identified: pulque (a drink of pre-Hispanic origin) and red worm. Women play an important role, participating in $80 \%$ of the preparation of both foods. The cultural environment of the maguey is a way of life that, in the case of the Ngigua people, represents a strategic element for survival. In times of food crisis, the study shows how ethnic food strategies in a context of ethical deliberation can constitute an alternative for the design of food solutions in territories with food shortages.
\end{abstract}

Keywords Food Ethic $\cdot$ Bioculture $\cdot$ Indigenous $\cdot$ Ngigua

\section{Introduction}

Historically, the maguey plant has been widely used by Mesoamerican cultures. According to Meggers (1975) the use of the plant among Mesoamerican indigenous populations dates back to 5000-3000 BC. Some studies place agricultural practices in Mesoamerica in the pre-classical period (2500 BC). During this period, the dynamics of human mobility slowed down, leading to the first human settlements (López 2001). This suggests that the indigenous people settled in Mesoamerica continued with their survival strategies, but maintained their ancestral food systems, which are still in place (Götz 2014; Woodward 2000). This implies

Diosey Ramon Lugo-Morin

diosey.ramon@uiep.edu.mx

1 Postgraduate Program in Sustainable Management of Natural Resources, Management of Socioecological Systems, Research and Postgraduate Studies, Intercultural University of Puebla State, Huehuetla, Mexico 
that indigenous people have had the capacity to incorporate external cultural elements on an ongoing basis (Lugo-Morin 2020). Through the exploration work carried out by Richard MacNeish, evidence was found of the use and management of the maguey plant by the Ngigua in the south of the Puebla state in Mexico. This is mentioned by the author as an element of survival (MacNeish and García, 1972).

According to MacNeish's studies, the ancestors of the Ngigua, the Oto-Manguean people, initiated the domestication of plants such as chili (Capsicum spp. L.), avocado (Persea spp. Mill.), pumpkin (Cucurbita spp. L.), maguey (Agave spp. L.) and other xerophyte species such as cactus (Opuntia spp. Mill.), more than 6,000 years ago (MacNeish and García, 1972). By 5000 B.C. they began to domesticate maize (Zea mays L.); and, in doing so, transformed the natural landscape into one based on crops. In particular, agriculture enabled human groups to achieve development in the economic, social, and cultural spheres. The cultivation of maize itself facilitated the emergence of great Mesoamerican civilizations (Paddock 1987; Gámez 2006).

As in the past, the current basis of the Ngigua diet is maize and its consumption is complemented by maguey, from the plant of which they produce a drink called "pulque". Similarly, the Ngigua diet includes worms, representing an important source of nutrients that are used in the preparation of various traditional dishes (Gámez, 2003, 2006).

The management of wild or cultivated plants has been carried out in different ways over time, either through biotechnological processes or traditional human selection. The latter strategy has been determinant in the diets of indigenous people (Chacón et al. 2005; HernándezTerán et al. 2017).

Traditional production systems have been the product of domestication processes of wild plants for thousands of years. This has resulted in a wide biodiversity, which is of great interest for modern agronomy and consequently for food security (Hernández-Terán et al. 2017). The human species has had to adapt to different natural scenarios in terms of food availability or scarcity. Thus, food is a factor of adaptive pressure over time (May and Ciocchini 2018).

Mexico is a multi-ethnic country with 68 identified indigenous groups, each culture has expressed its own worldview on life and explores various adaptive strategies to ensure its survival. The Ngigua, indigenous people settled in southern Puebla, Mexico have maintained these principles and have adopted adaptive strategies aimed at the use of the maguey plant. The use of maguey by the Ngigua indigenous group has been extensively documented (MacNeish and García, 1972; Meggers 1975). The Ngigua have developed their food strategies taking into account the agro-ecological conditions of their territory, where xerophytic species (vegetation adapted to life in the arid environment), such as the maguey plant, predominate. At the same time, these people have been able to take advantage of agriculture based on the cultivation of maize.

Based on the need to design strategies to address food security in semi-arid territories, this study aims to identify the food uses associated with the maguey plant from a biocultural perspective among the Ngigua indigenous people of the municipality of Tlacotepec de Benito Juárez in the state of Puebla.

\section{Food ethics, Indigenous Peoples and the Right to Adequate Food}

Food ethics in the indigenous context is associated with a historical and profound relationship that indigenous groups have with nature. This way of perceiving this relationship shapes the indigenous food system and diet (Racz et al. 2018). 
But this reality may encounter adverse environments (e.g., globalisation) that may influence the dynamics of ethnic food habits, particularly in indigenous populations close to large cities. These causal relationships reconfigure the boundaries of standard ethical issues correlated with food security. According to Reddy and van Dam (2020) the choice of food practices can be influenced by the predominant identity held by a place or territory.

The agricultural practices of indigenous are underpinned by an ancestral legacy (Valle 2021; Lugo-Morin 2020). This legacy has generated in indigenous a system of beliefs, values and traditions where food ethics is an element that articulates with nature.

In today's world, where the COVID-19 pandemic has destabilised food ethics, we see with concern how the global food value chain is not driven by ethical deliberation but by competing values and power dynamics (Kaiser et al. 2021). Given this reality, the experiences that emerge in indigenous contexts constitute lessons that a post-covid-19 scenario can generate alternatives for building a new food ethic.

According to Kaiser et al. (2021) the aftermath of the COVID-19 pandemic may trigger a new ethical food future in the world, a post-pandemic food ethic. We do not know how intense the local dynamics may be in imposing new ways of reorienting food systems, but what we do know is that we can probably take for granted a watershed in food systems: a before and after COVID-19.

Global governance has highlighted the importance of indigenous peoples' right to adequate food guided by their belief systems, values and traditions (Fakhri, 2015; FAO et al. 2019). According to UN (1999) "The right to adequate food is realized when every man, woman and child, alone or in community with others, has physical and economic access at all times to adequate food or means for its procurement" These rights have four pillars: availability, accessibility, adequacy and sustainability.

The right of indigenous people to adequate food is embodied in a global legal structure driven by global governance. The following legal tools are identified: i) Article 11 of the ICESCR (UN 1999); ii) The declaration by the FAO Council in 2004 (FAO 2006); iii) The United Nations Declaration on the Rights of Indigenous People in September 2007 (UN 2007); iv) Convention No. 169 (ILO 2013) and v) The 2030 Agenda for Sustainable Development-Goals 2 and 4. (UN 2015). This international legal framework protects indigenous people from violations of access to adequate and culturally acceptable food. According to FAO (2009) the human rights-based approach provides a normative basis for the rights of each of the world's indigenous people to feed themselves in accordance with their territorial conditions and culture.

The United Nations Human Rights Council, through the Report of the Special Rapporteur on the Right to Food, has emphasised that traditional knowledge is a fundamental aspect in the preservation and promotion of food systems (UN 2020). By including the term "traditional knowledge", reference is made to indigenous people, among others. FAO argues that minority groups, including indigenous groups, are a food-deficient segment of the global population (FAO et al. 2019). But FAO's position is debatable as it is a generalisation that does not occur in all indigenous territories, perhaps indigenous needs are more oriented towards accompanying the design of public policies that protect their belief systems, values and traditions because most food systems rely on these systems.

According to FAO et al. (2019) indigenous food involves the production of diverse foods with minimal negative impact on the environment. These systems are based on ancestral knowledge that relies on sustainable management of biodiversity, which ensures adequate dietary diversity. Many wild and cultivated species provide the nutrients necessary for the development of age groups. 
Understanding what the right to food means for indigenous people is complex. Indigenous people define through their worldviews what constitutes adequate food. Food, its access and consumption are often an important part of their culture, as well as of their social, economic and political organisation. This way of perceiving food is an ethical stance from ancient times and its meaning becomes relevant within the framework of their belief systems, values and traditions (UN and FAO 2010).

\section{Ethics and Biocultural Resources}

Ethics in biocultural food is approached timidly, ethics when approached from the culturenatural resources synergy disrupts the ideals and values that arise from Western hegemonic thinking, for example we talk about the high food consumption in megacities, the food waste that is generated by controlling the sale prices of many food products and the food value chains that do not perceive the importance of small-scale agriculture or family farming.

The logic of the above approach guides the debate that actions driven by global capitalist logic are deliberately unethical and, in many countries, governments are constitutionally obliged to provide their citizens with food security. According to Burkhardt (2012) food security is a public good, which means that governments have ethical obligations to their citizens to protect that public good. If we place this approach in the indigenous context, we see that indigenous territories are subject to systematic neglect, probably indigenous peoples who have survived for millennia without the tutelage of the state do not require support, but indigenous peoples close to large cities require support in terms of public food policies.

Mexico, as part of Mesoamerica, is a highly diverse and multicultural country with 315 language variants. A high degree of convergence between indigenous territories and natural protected areas has been documented (Toledo 2006). Better conservation conditions in the ecosystem derived from the traditional action of a certain ethnolinguistic group have been determined through specific research. In this regard, the biocultural approach stands out because it considers that culture is an element that interacts between society and nature itself, thus determining how human subsistence occurs (Luque et al. 2018). It all happens because human beings possess a language and teaching that allow for a very high-fidelity transmission of information and, consequently, lead to very long-lasting traditions and massive amounts of culture (Laland and Rendell 2013). For this reason, indigenous peoples are regarded as the guardians of the biocultural memory of the human species throughout life on the planet, an element that is sustained by biocultural diversification. Toledo and Barrera-Bassols (2008) likewise, these peoples are recognized as factors that have a significant impact on the stability of ecosystems and the way the global climate is regulated.

In general, every culture that inhabits a given territory survives, persists, and resists because of its own natural support or environment. Nature supports culture, and culture provides meaning to nature in its territory. Nature is appropriated intellectually and materially through human work. It ends up being humanized through the domestication of species, water, vegetation, and landscapes (Toledo 2018).

According to Gorenflo et al. (2012), the phenomenon of "co-occurrence" takes place through the integration of biodiversity and biological endemism with linguistic diversity and endemism. By using global cartographic databases, these authors identified regions with the greatest presence of biodiversity and that are strategic for 
conservation. These areas are referred to as biodiversity hotspots and high biodiversity wilderness areas and subsequently compared with the help of updated ethnolinguistic maps. Researchers reported that, of the 6,900 languages currently spoken on Earth, more than 4,800 non-migrant indigenous languages are distributed in areas of high biodiversity. Nearly half of these languages-3,202, of which 2,166 are endemicare located in 35 biodiversity hotspots, particularly on the islands of Eastern Melanesia. This proportion is also found in the forests of Guinea in West Africa, the IndoBurmese region, Mesoamerica (central and southeastern Mexico and part of Central America) and Wallacea in Indonesia (Gorenflo et al. 2012).

The body of knowledge of local self-subsistence systems, such as those related to gathering, hunting, fishing, and cultivation, present in indigenous people, make up invaluable assets of knowledge. To date, its efficiency in relation to the communities' own food security has not been evaluated in a contemporary manner. This is part of an effort to recognize the human rights connected to food (Wu et al. 2014; Luque et al. 2018). The maguey plant is an important biocultural resource, especially present in the reproduction strategies of the Ngigua. Giving it the right value from the people's worldview is something usual. This value leads to new strategies for the use and management of the plant, thus incorporating actions for low-income families that inhabit desert territories.

\section{Food Ethics in Ngigua Diet}

In each ethnic group, food varies according to their belief systems, values and traditions, as well as the agro-ecological conditions of the territory, such is the case of the Ngigua, who make use of xerophytic species such as the maguey, which they treat in a traditional way. Despite the technological transformations, the Ngigua continue to treat the maguey in the same way as their ancestors did, and its use and treatment has been passed down from generation to generation. The maguey represents for them an endemic plant as it is part of their territory, which is accompanied by a cultural mediation determined by informal institutions such as: the offerings in honour of their deities to whom they offer maguey in different foods; the dances where they use maguey as ornaments for their ceremony; as traditional medicine and as part of their food diet. With each of the uses they give to the maguey; they treat it with respect and care.

In this sense, the Ngigua, since ancient times, have acted ethically in the proper use of the maguey plant and in passing on the traditional knowledge associated with it. At present, this knowledge may be negatively affected due to the economic dynamics of foreign capital in the region, in particular the investment of Chinese companies; this means that the territories historically occupied by the Ngigua may, in the future, suffer a transformation that will impact on their informal institutions. These ideas are contextualised by Nazarea et al. (2013) who points out the need for spaces for traditional ways of life to develop, the logic of capital and consumerism is increasingly present in these spaces, generating precariousness in the right to adequate food.

The food value that the Ngigua attach to the maguey plant enters the collective sphere, as this plant is part of the adaptive strategies that this group has developed to preserve their right to food. 


\section{Methods}

\section{Setting and participants}

The study was conducted in the municipality of Tlacotepec de Benito Juarez in the Puebla state in Mexico, which is located in the southeast of the State between parallels $18^{\circ} 30^{\prime}$ and $18^{\circ} 46^{\prime}$ north latitude; meridians $97^{\circ} 29^{\prime}$ and $97^{\circ} 46^{\prime}$ west longitude; at an altitude between 1,880 and 2,900 $\mathrm{m}$ above sea level (Fig. 1).

It presents a level of rainfall ranging between 400 and $800 \mathrm{~mm}$, which configure a semidry temperate climate $(61 \%)$; temperate subhumid with rainfall in summer, lower humidity (29\%) and temperate subhumid with rainfall in summer, average humidity (10\%). The municipality is integrated by 53 localities, which are home to 17,066 indigenous people, who belong to the Ngigua (SEDESOL 2007; IPPI 2020). From these 53 localities, the three main communities of the municipality that take advantage of the maguey plant were chosen: San Marcos Tlacoyalco; San Martin Esperilla and Parmillas.

According to official sources, seven indigenous groups (Nahua, Totonac, Ngigua, Mazatec, Hñähñu, Mixtec and Tepehua) occupy the Puebla state, representing a total indigenous population of 645,348 inhabitants (IPPI 2020). Of these, 17,066 (2.64\%) belong to the Ngigua people, all of whom inhabit the municipality of Tlacotepec de Benito Juarez (Fig. 1). This municipality is characterized by a high degree of marginalization, with $26.7 \%$ of the population living in deep poverty (IPPI 2020; SEDESOL 2007). The south of Puebla has been considered a region of ethnic importance; evidence shows that it was in this region

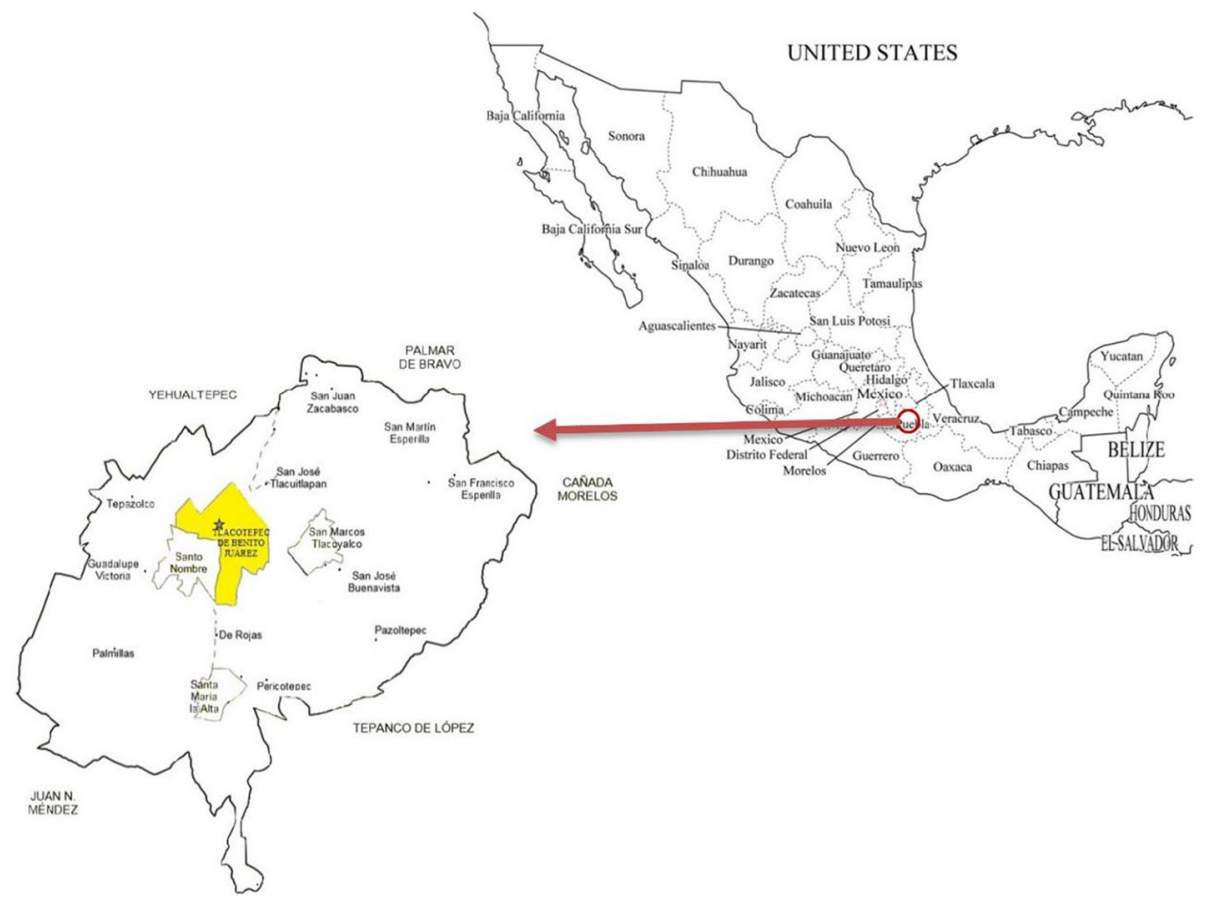

Fig. 1 Geographical location of the municipality of Tlacotepec de Benito Juarez and major settlements 
where maize (Z. mays) was domesticated (MacNeish and García, 1972). From very early times, the Ngigua inhabited this region, being this culture the oldest inhabitants (Gámez 2006).

\section{Qualitative interviews}

To achieve the proposed objective, a qualitative approach supported by the sampling technique (semi-structured interview) was employed in the study. The interviews were carried out with the support of both students from the fourth semester of the bachelor's degree in Sustainable Development at the Intercultural University of Puebla State and the authorities of the municipality of Tlacotepec de Benito Juarez. Interviews were conducted in the three study communities, visiting their homes and fields, and all interviews were conducted orally and in writing. During the interview process, the food uses of maguey were exemplified directly in the field.

The questions were aimed at identifying the use and management of the maguey plant in a historical and current context; and the preparation of food considering the worldview of the people and the plant as a highly available natural resource. Each interview lasted three hours and was conducted in Spanish and in Ngigua. In cases where translation was needed in the group of interviewers there were several Ngigua indigenous students who were able to translate the cases mentioned.

The information derived from the interviews was systematized and analyzed descriptively through the following categories: informal institutions, territory, bioculture, maguey and food use of maguey, which allowed us to understand the biocultural logic around maguey and to elaborate the results described in this document.

The geographical location of respondents was determined by the snowball sampling technique (Snijders 1992). Under this approach, the initially selected individuals helped to identify other individuals with the characteristics that the study required.

\section{Findings and Discussion}

The field work was carried out in November 2019 and involved 27 semi-structured interviews, which were organized as follows: 11 interviews in the community of San Marcos Tlacoyalco; 12 interviews in the community of San Martín Esperilla; and 4 interviews in the community of Parmillas. The interviews were conducted with Ngigua people, both men and women, and the interviewees were between 25 and 75 years old. In this age range, $30 \%$ corresponded to women and men between 30 and 40 years old. While $70 \%$ corresponded to women and men between the ages of 50 and 75 .

During the interviews, the indigenous women mentioned that they play an important role in the preparation of the food associated with the maguey plant; $80 \%$ of the activities derived from this item are carried out by the women. While men dedicated $20 \%$ of their time to this same item.

Bioculture and informal institutions were highlighted in the interviews by women and men over 50 years of age, pointing out how the maguey contributes to the strengthening of Ngigua cultural expressions and food. This association, which also includes the territory, shapes the ethnic food ethic, and several of the interviewees' testimonies highlight the value of beliefs, values and traditions in the perception of the Ngigua food ethic. 
The study during its development had several limitations; the main limitation was the mobility restrictions of the interviewing group due to crime in one of the communities where interviews were applied, to solve the problem it was necessary to request protection support from the local police. Another limitation was the transfer to the study communities within the municipality to carry out the interviews; the lack of transport made the transfer difficult, which could be solved by requesting transport support from the authorities of the municipality.

The study was carried out with respect for the traditions of the indigenous people, previously permission was requested from the municipal authorities and wisemen from the indigenous communities, which gave their approval. The committee that endorsed and approved the study was formed by the university authority represented by the rector of Intercultural University of Puebla State and the municipal authority Mr. Nelson Feliciano Beristain Macias.

\section{The food use of maguey in the Ngigua indigenous}

The women's activities associated with the preparation of maguey-related foods include handling the plant to extract the sap, the fermentation process and the packaging of the sap (pulque). They are also in charge of making salt and sauce from maguey worms. These women have acquired traditional knowledge from their mothers when they were children. The men are involved in the agronomic management of the plant, cleaning the land and collecting the maguey worms, the younger men are in charge of searching for and collecting the worms. Like the women, the knowledge was acquired from father to son. Data collected during the interviews identified several species of maguey used by the Ngigua. See Fig. 2 shows the most representative species.

See Fig. 3 shows the different uses that the Ngigua people assigns to the maguey species in Tlacotepec de Benito Juarez. For this study, the following three alimentary uses are considered: Salt of tecol, sauce of tecol and pulque, corresponding to the items mentioned in Fig. 3 as Drink and Food.

Other non-food uses of maguey were identified in the three study communities: as construction material, medicinal, biomass for fuel (firewood), as a windbreak (environmental protection) and mezcal (liquor).

Construction material (Building): the use of maguey in construction is mainly in the communities of San Miguel Tlacoyalco and San Martin Esperilla, the uses identified are roofs for homes, construction of corrals for smaller species of birds: chickens. The species used are: A. salmiana, A. americana or Agave peacockii Croucher. Medicinal: maguey has a widespread medicinal use in the three study communities; the most common uses in the three communities are: diabetes, energizer for sexual intercourse or skin wounds. The most used species are A. salmiana and A. americana. Firewood: once the maguey completes its life cycle, it is put to dry and can be used as firewood, all the species of maguey are used. This practice is common in the three study communities: San Miguel Tlacoyalco, San Martin Esperilla and Parmillas. Environmental protection: maguey is widely used as environmental protection during the handling of some crops such as maize (Z. mays). The most used species are: Agave karwinskii Zuccarini, A. americana, A atrovirens or Agave marmorata. This practice is very common in the communities of San Miguel Tlacoyalco and San Martin Esperilla. Elaboration of mezcal (liqueur): practiced in a handmade way in the community of Palmillas, the species used is Papalome (Agave potatorum Zuccarini). 

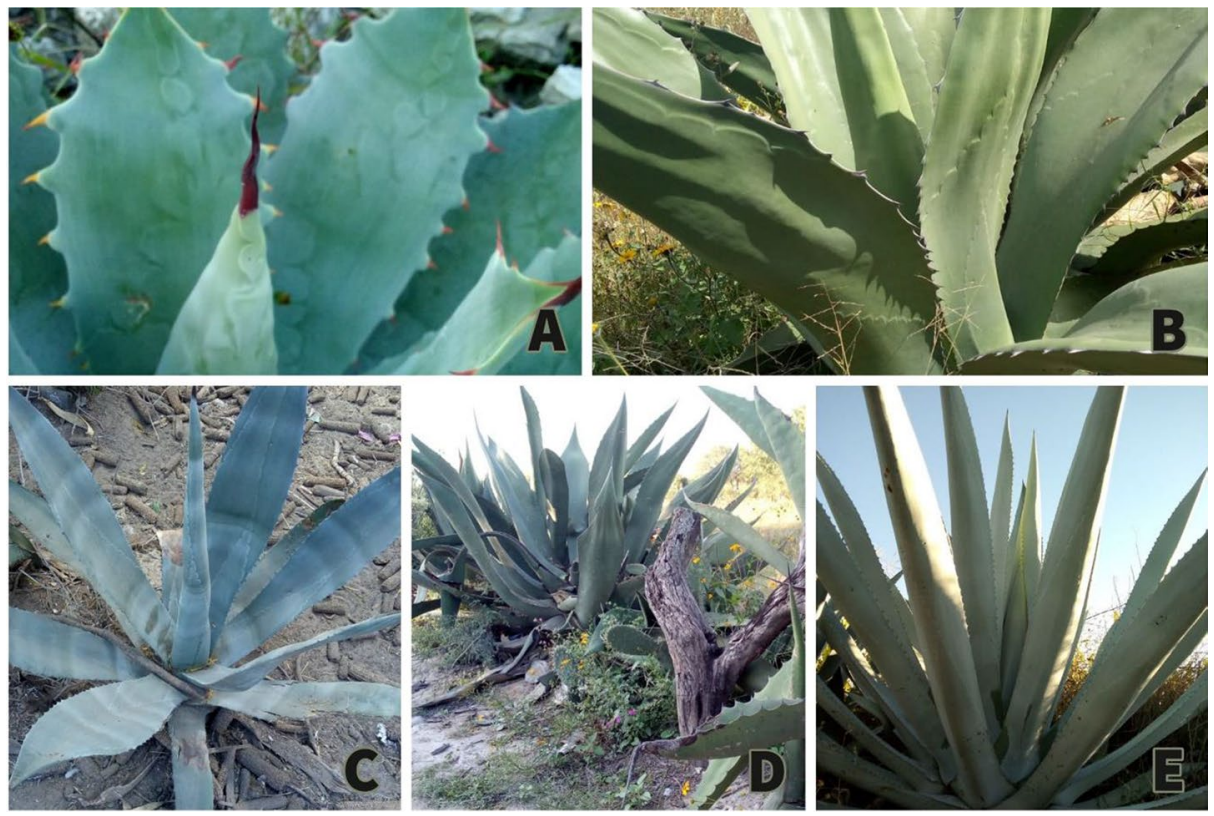

Fig. 2 Maguey plant identified associated with the feeding strategies of the Ngigua of the municipality of Tlacotepec de Benito Juarez. a: A. potatorum; b: A. salmiana; c: A. americana; d: Agave angustifolia; e: Agave tequilana. Note: The maguey species: B, C, D are used to make: tecol salt, tecol sauce and pulque. These species are distributed in the three localities (San Marcos Tlacoyalco, San Martin Esperilla and Parmillas) in the municipality of Tlacotepec de Benito Juarez south of Puebla

The analysis of the interviews shows that the maguey plant is important in the Ngigua People. The following testimonies show the importance of the maguey for the Ngigua People.

We here in our town have used maguey since ancient times, that knowledge has been passed from generation to generation, we give it different uses (Ngigua indigenous woman, Community of San Marcos Tlacoyalco, Nov. 2019).

Since we sow the maguey, we have to wait several years before using it, traditionally the maguey is important for us not only do we use it in food, but also in our traditional festivals as an offering (Ngigua indigenous man, Community of San Martin Esperilla, Nov. 2019).

The maguey plant is an important biocultural resource historically used by the Ngigua in different ways, mainly as a food subsistence strategy in the semi-arid territories occupied by the group. In addition to food security, the Ngigua culture uses the plant in traditional dances, housing, and medicinal use, as demonstrated by the culture's oral tradition. According to Narváez et al. (2016) in the Mexican states, such as Veracruz, Tlaxcala, Hidalgo and the State of Mexico, the food use of the maguey plant is broad and includes quiote, eggs and flowers, elements that included in various dishes (e.g., gualumbos, juice and dulce de quiote). They are part of the diet of peasant families. This work of Acuña et al. (2011) shows the multifunctionality that, within an indigenous worldview, the use and exploitation of the maguey plant may have. This view has been enriched since times 


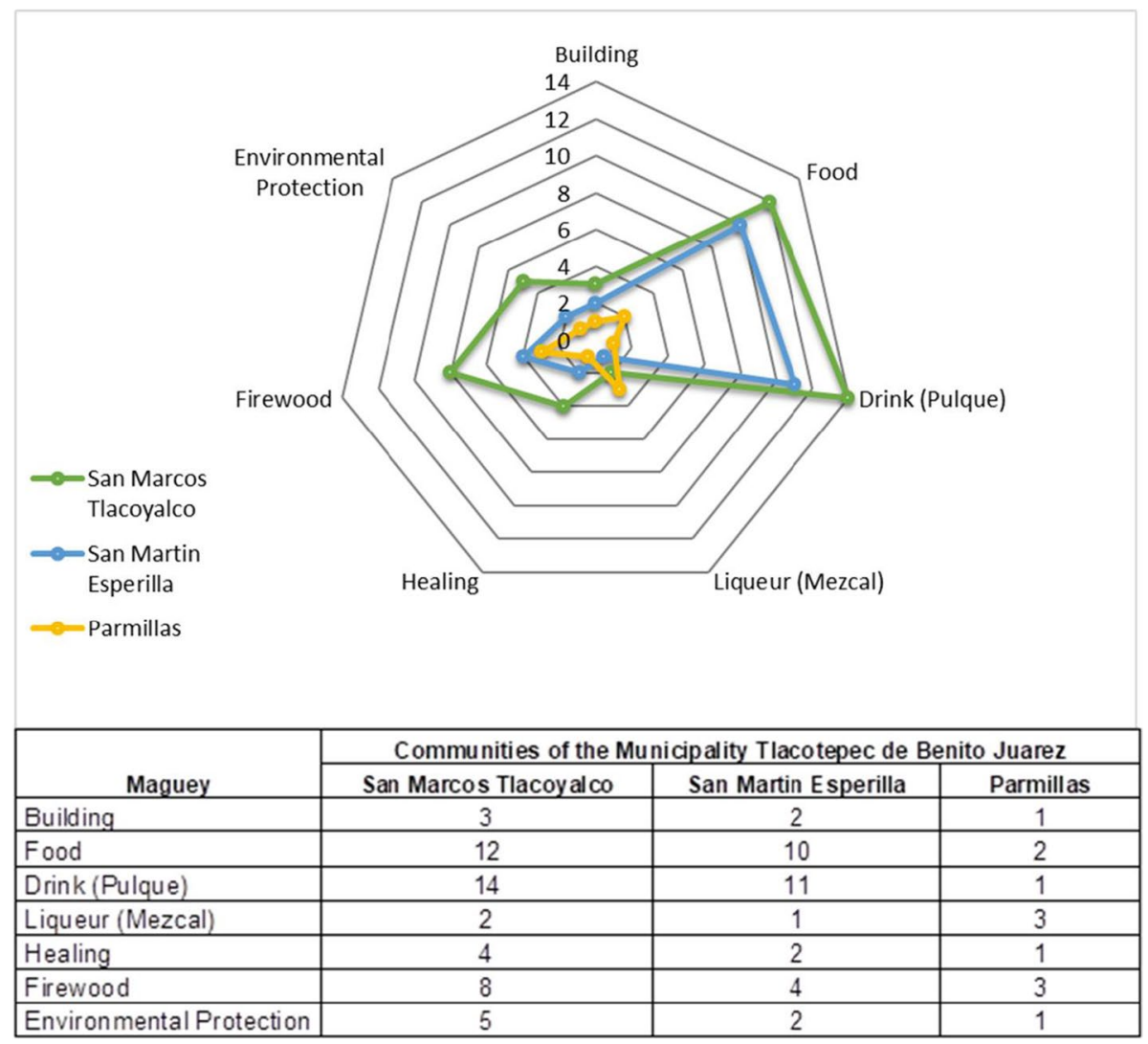

Fig. 3 Maguey uses in the municipality of Tlacotepec de Benito Juarez

before the Spanish Conquest, as the Florentine Codex demonstrates (Sahagún, 1577: 115). The testimony of an indigenous wise shows the importance of the maguey for the survival of the Ngigua People.

I am 75 years old and when I was a child my father taught me how to handle the maguey. In the oral tradition of the Ngigua the maguey has always been important to us, the maguey has been collected in our desert territory since ancient times, there is not much water here, but the maguey grows well (Ngigua indigenous man, Community of San Marcos Tlacoyalco, Nov. 2019).

\section{Human use of Insects as Biocultural Food}

The analysis of the data obtained from the interviews recognizes a wide use and management of the maguey, including its alimentary use in a direct and indirect way. Women are involved in food preparation, the pulque and tecol stands out. This last food is used the maguey red worm (Comadia redtenbacheri Hammerschmidt) to make salt and sauce that would later be used to complement other foods. The men carry out the work in the fields 
such as sow the maguey plant and managing it. Young indigenous people have the task of collecting the red worm in the months of September and October.

Literature reports for Mexico at least 67 species of Lepidoptera for human consumption, more than $85 \%$ is consumed in its larval state. Among the species that are part of the ethnic diet of the indigenous people of the State of Puebla, they are mentioned: Comadia redtenbacheri Hammerschmidt, Aegiale hesperiaris Walker, Eucheira socialis socialis Westwood, Nymphalis antiopa antiopa Linnaeus, Pareuptychia metaleuca Boisduval, Danaus gilippus thersippus Bates, Danaus plexippus plexippus Linnaeus, Bombyx mori Linnaeus, Eutachyptera psidii Sallé, Arsenura armida Cramer, Arsenura polyodonta Jordan, Caio championi Druce, Paradirphia hoegei Druce, Paradirphia fumosa Felder, Ascalapha odorata Linneaus, Gerra sevorsa Grote and Latebraria amphipyroides Guenée (RamosElorduy et al. 2011).

The testimony of a young indigenous woman points to the use they give to the maguey red worm.

When I was a child, my dad taught me everything about maguey, in the family I have the task of collecting the red worm in the months of September and October, my mom uses it to make salt and sauce (Ngigua indigenous young, Community of San Marcos Tlacoyalco, Nov. 2019).

Red-colored worm ( $C$. redtenbacheri), a lepidopteran of the Cossidae family, is used in the production of salt and sauce in the three Ngigua communities studied (see Fig. 4). Its nutritional contributions include Vitamin $C(17.58 \mathrm{mg} / 100 \mathrm{~g})$, Vitamin B1 (Thiamine) $(0.31 \mathrm{mg} / 100 \mathrm{~g})$, Vitamin B2 (Riboflavin) $(0.46 \mathrm{mg} / 100 \mathrm{~g})$ and Vitamin B3 (Niacin) $(1.83 \mathrm{mg} / 100 \mathrm{~g})$. This feeding strategy allows the group to have a balanced and nutritious diet prevalent in semi-arid conditions. It is an essential source of nutritious food for the subsistence of the communities (Ramos-Elorduy and Pino 2001; Acuña et al. 2011).

The nutritional composition of insects is very diverse compared to commonly eaten meats. The 'insect' food category can be effective in fighting malnutrition (Payne et al. 2016). A diet rich in insects is common in both developed and developing countries, with the former being an exotic culinary alternative, while the latter is a food strategy that responds to the malnutrition prevalent within the poorest communities (Ramos-Elorduy et al. 2007). In many European countries, the concept of insects as food is still unknown,

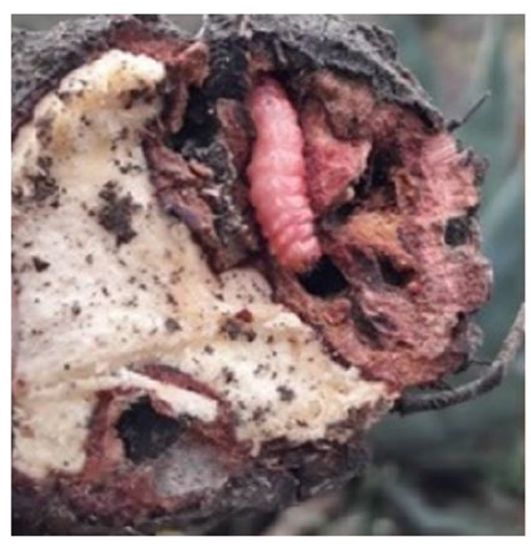

\section{Comadia redtenbacheri}

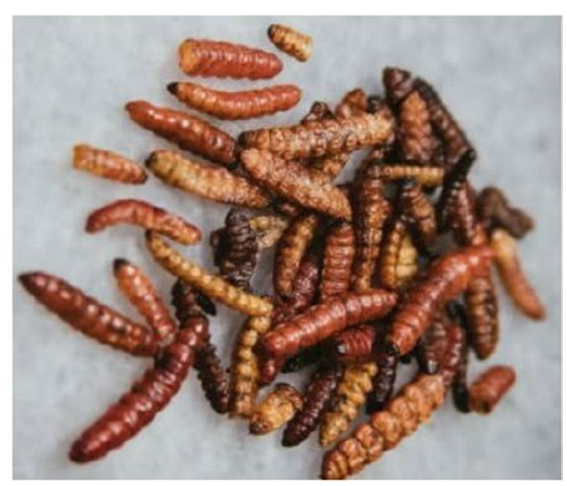

Fig. 4 Red worm specimen 
perhaps in the future their potential may be considered (Wassmann et al. 2021). Insects in many parts of the world are considered nutritious foods. This food source is a relevant strategy for vulnerable territories, but its consumption has yet to be evaluated to avoid the toxic substances that some insect species may contain (Ribeiro et al. 2021).

FAO documents more than 2000 species of edible insects consumed worldwide. Compared to other forms of production, the production of edible insects has the potential to contribute positively to sustainable development and mitigate hunger in territories with food poverty (Van Huis et al. 2013).

The red worm ( $C$. redtenbacheri) resides inside the maguey plant (A. salmiana). Regarded as a pest, it damages the plant to the point of death. According to Acuña et al. (2011) a yellowish color in the plant means the presence of the worm. The latter is collected from the bottom and then boiled or fried, and finally ground and mixed with sauce and spices. The red worm is commonly referred to as tecol among the inhabitants of the municipality of Tlacotepec de Benito Juarez. Its consumption is part of the Ngigua daily life which, according to Vázquez et al. (2016), occurred since pre-hispanic times as shown in the Florentine Codex. Figure 5 explains the elaboration process of tecol salt and sauce.

\section{Pulque as a biocultural food}

Pulque is a mexican drink of pre-hispanic origin, it is made from the sap of the maguey called "honey water" (Parsons and Darling 2000). The species of importance for the production of "pulque" are: Agave americana L., Agave atrovirens Karw. ex Salm-Dyck, Agave ferox K. Koch, Agave mapisaga Trel., Agave marmorata Roezl, Agave salmiana Otto ex Salm-Dyck (Gentry 1982; Garcia-Mendoza 2011).

It is a fermented drink obtained from the sap of the plant and is known as mead when the sap itself is obtained by scraping the heart of the plant. When the plant has matured enough it must be "capped or castrated", these terms mean to extract the apical flower bud to ensure that as much sap as possible is obtained. Once this action is done, the plant is no longer known as "capon" (Vázquez et al. 2016). See Fig. 6 shows the pulque production process used by the Ngigua. The preparation is the same in the three locations studied.

The maguey is an endemic plant of the Americas, of which there are approximately 200 species on the continent, being 150 found in Mexico. The pulquero variety is largely distributed across the Central Mexican Altiplano, where it has been used for various purposes over time. It is a source of raw materials, prevents soil erosion and is a host to the red worm (Narváez et al., 2016).

Pulque is an ancestral ethnic drink that has now acquired food importance among non-indigenous groups. Its distribution covers the whole Mexican territory with emphasis on those with indigenous presence. The chemical and nutritional properties of pulque have been evaluated, provides calories (12\%), total protein $(6 \%)$, thiamin $(10 \%)$, riboflavin (24\%), niacin (23\%), vitamin C (48\%), calcium (8\%), and iron (51\%) (Escalante et al. 2016).

The mechanisms of interaction of the Ngigua with nature provide sustenance for their survival, the attributes of plants from a biocultural perspective from the reality of Mesoamerican indigenous societies such as the Ngigua allow us to move towards a way of perceiving and practicing sustainability and ethics. In a world where the environment is being severely disturbed by human actions, indigenous societies and their resilience teach us that interactions with nature can reach a symbiotic level that benefits the species involved. In the words of Nazarea et al. (2013) understanding that indigenous people and their often-edible environment 


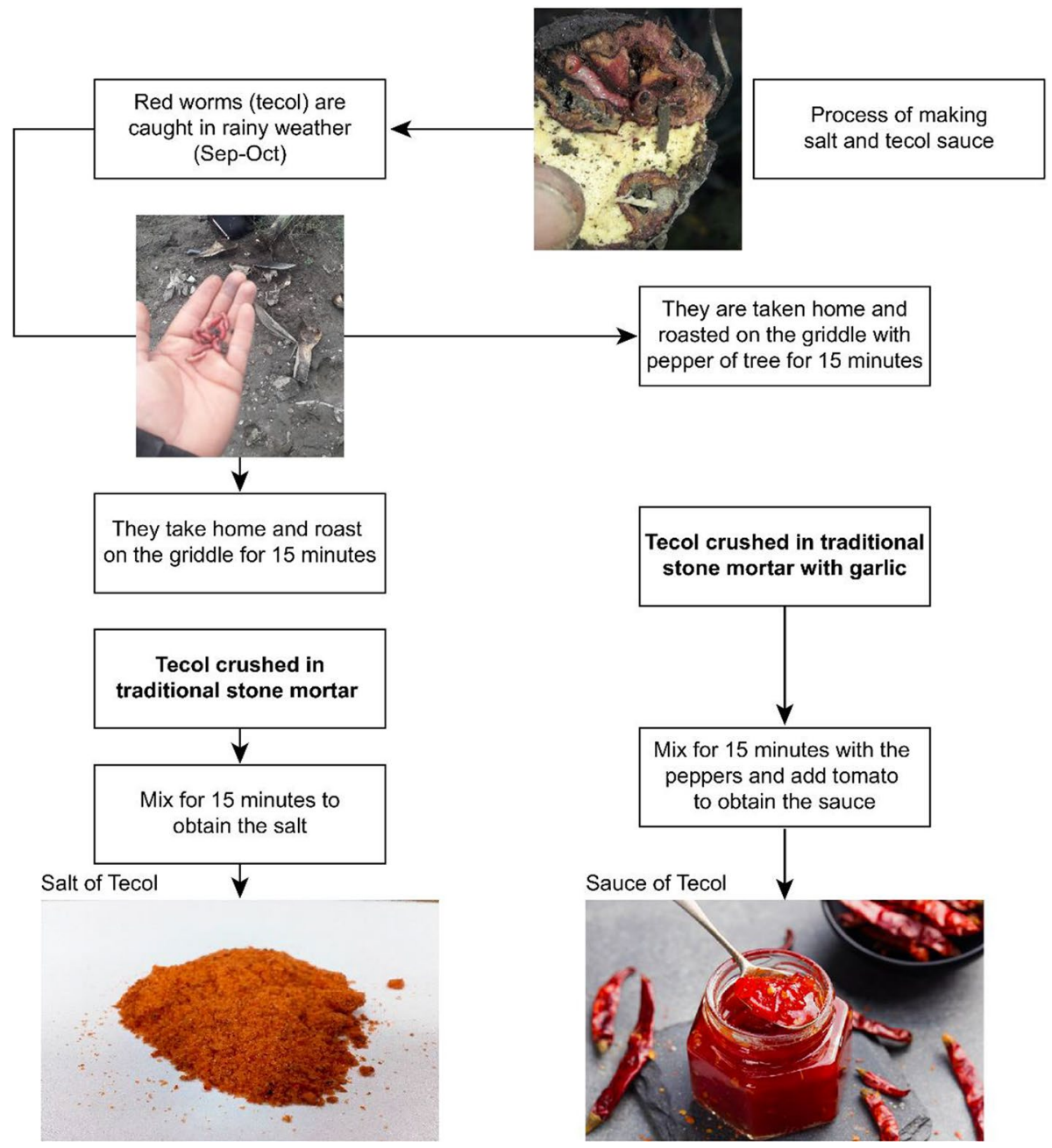

Fig. 5 Tecol salt and sauce production. This process is exclusive to the Ngigua in the municipality of Tlacotepec de Benito Juarez. It may change by region and indigenous group

are related through bonds of kinship, spiritual reverence and respect, rather than separation and domination is an urgent task.

Modern civilization in the framework of an advanced social metabolism is reaching planetary limits in the use of natural resources (Haberl et al. 2021), the way in which indigenous societies interact with their environment can provide a new vision of sustainability in the framework of natural resources (Lugo-Morin 2021). 


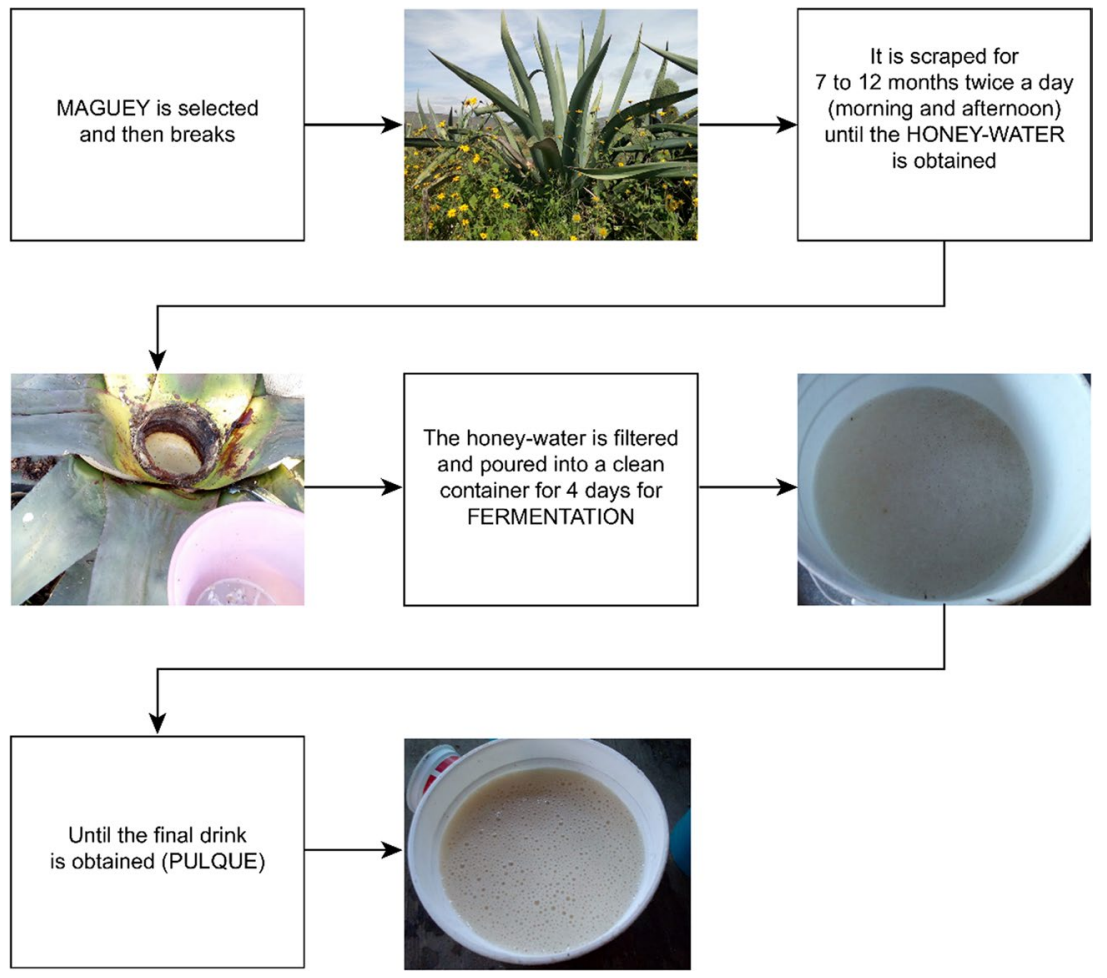

Fig. 6 Pulque elaboration by the Ngigua in the municipality of Tlacotepec de Benito Juarez

\section{Conclusion}

The study identified the different uses of maguey by the Ngigua people of the municipality of Tlacotepec de Benito Juárez, highlighting two uses in the food context, pulque and tecol. The importance of the maguey plant as an ethical biocultural food for the Ngigua is supported by the results of the study. The analysis of the results shows the relevance of informal institutions in the food use given to maguey, the value of their belief system, values and traditions accentuates the link with the maguey plant. In this situation, the Ngigua people have perpetuated the ancestral knowledge they have about Maguey, the system of belief, values and traditions are part of a structure that keeps alive the tradition of ethics food associated with maguey. The work carried out by indigenous women and youth is recognized and they guarantee that maguey is a strategic biocultural resource for has survival.

While us focused on one case study within Ngigua indigenous bioculture, the development of a nomothetic framework may prove useful in other geographic and developmental contexts. Many territories have a biocultural wealth, but they have been forgotten, the protection of this ancient knowledge ensures the survival of these territories and their people.

Acknowledgements The author wishes to express his gratitude to the communities that participated in the dialogue of knowledge, as well as to the authorities of the Municipality of Tlacotepec and the Intercultural University of Puebla State for the support granted. A special thanks to the students of the third semester of the degree program in sustainable development of the Intercultural University of Puebla State who participated in the dialogue of knowledge: Areli Teodora Sosa Primitivo, Belén Pérez Bonilla, Cristopher García 
Torres, David Moreno Álvarez, Adriana Bautista Vázquez, María Isabel Méndez Fernández, Pablo César López Lopez and Araceli Ramírez Juárez

Funding This study was funded by the Intercultural University of Puebla State in September 2019.

Availability of data and materials All data and materials have been presented in the paper.

\section{Declarations}

Competing interests I declare that there is no conflict of interest.

\section{References}

Acuña, A.M., L. Caso, M.M. Aliphat, and C.H. Vergara. 2011. Edible insects as part of the traditional food system of the popoloca town of los reyes metzontla Mexico. Journal of Ethnobiology 31 (1): 150-169.

Burkhardt, J. 2012. The Ethics of Food Safety in the Twenty-First Century. Who Keeps the Public Good? Pp. 140-160. In The philosophy of food. Kaplan, D (Editor). Los Angeles-London: University of California Press.

Chacón, M., B. Pickersgill, and D. Debouck. 2005. Domestication patterns in common bean (Phaseolus vulgaris L.) and the origin of the Mesoamerican and Andean cultivated races. Theoretical and Applied Genetics 110: 432-444.

Escalante, A., D.R. López Soto, J.E. Velázquez Gutiérrez, M. Giles-Gómez, F. Bolívar, and y López-Munguía A. . 2016. Pulque, a Traditional Mexican Alcoholic Fermented Beverage: Historical, Microbiological, and Technical Aspects. Frontiers in Microbiology 7: 1026.

Fakhri, M. 2015. Food as a Matter of Global Governance. Journal of International Law and International Relations 11 (2): 68-83.

FAO, IFAD, UNICEF, WFP and WHO. 2019. The State of Food Security and Nutrition in the World 2019. Safeguarding against economic slowdowns and downturns. Rome: FAO

FAO. 2006. The right to food guidelines: Information papers and case studies. Rome: FAO. Available online: http://www.fao.org/3/a0511e/a0511e.pdf

FAO. 2009. The right to adequate food and indigenous peoples: How can the right to food benefit indigenous peoples? Rome: FAO.

Gámez, A. 2003. Los popolocas de Tecamachalco-Quecholac: Historia, cultura y sociedad de un señorío prehispánico. Puebla: Benemérita Universidad Autónoma de Puebla.

Gámez A. 2006. Popolocas. Pueblos indígenas del México contemporáneo. México: Comisión Nacional para el Desarrollo de los Pueblos indígenas. http://www.cdi.gob.mx. Accessed 29 February 2020.

Garcia-Mendoza, A. 2011. Agavaceae. Flora Del Valle De Tehuacán-Cuicatlán 88: 1-95.

Gentry, H.S. 1982. Agaves of continental North America. Arizona: University of Arizona Press.

Gorenflo, L.J., S. Romaine, R.A. Mittermeier, and K. Walker-Painemilla. 2012. Co-occurrence of linguistic and biological diversity in biodiversity hotspots and high biodiversity wilderness areas. Proceedings of the National Academy of Sciences of the United States of America 109 (21): 8032-8037.

Götz, C.M. 2014. La alimentación de los mayas prehispánicos vista desde la zooarqueologia. Anales De Antropología 48: 167-199.

Haberl, H., Schmid, M., Haas, W., Wiedenhofer, D., Rau, H. and Winiwarter, V. 2021. Stocks, flows, services and practices: nexus approaches to sustainable social metabolism. Ecological Economic 182: 106949.

Hernández-Terán, A., A. Wegier, M. Benítez, R. Lira, and A.E. Escalante. 2017. Domesticated, Genetically Engineered, and Wild Plant Relatives Exhibith Unintended Phenotypic Differences: A Comparative Meta-Analysis Profiling Rice, Canola, Maize, Sunflower, and Pumpkin. Frontiers in Plant Science 8: 2030.

ILO. 2013. Understanding the indigenous and tribal people convention, 1989 (No. 169). Handbook for ILO Tripartite Constituents/International Labour standards Department. Geneva: International Labour Organization. Available online: https:/www.ilo.org/wcmsp5/groups/public/---ed_norm/---normes/ documents/publication/wcms_205225.pdf

IPPI. 2020. Etnias del estado de Puebla. Subsecretaria de Atención a Pueblos Indigenas. Instituto Poblano de los Pueblos Indigenas http://ippi.puebla.gob.mx/es/\#k2ModuleBox104. Accessed 27 February 2020 
Kaiser, M., S. Goldson, T. Buklijas, P. Gluckman, K. Allen, A. Bardsley, and M.E. Lam. 2021. Towards post-pandemic sustainable and ethical food systems. Food Ethics 6: 4.

Laland, K.N. and Rendell, L. 2013. Cultural memory. Current Biology 23(17): PR736-PR740.

López A. 2001. El núcleo duro, la cosmovisión y la tradición mesoamericana. In: Broda JY, Báez-Jorge F, et al., editors. Cosmovisión, ritual e identidad de los pueblos indígenas de México. México: Consejo Nacional para la Cultura y las Artes-Fondo de Cultura Económica, p. 47-65.

Lugo-Morin, D.R. 2020. Indigenous communities and their food systems: A contribution to the current debate. Journal of Ethnic Foods 7: 6.

Lugo-Morin, D.R. 2021. Global Mapping of Indigenous Resilience Facing the Challenge of the COVID19 Pandemic. Challenges 12 (1): 15.

Luque D., Martínez-Yrizar A., Búrquez A., López G. and Murphy A. 2018 Los complejos bioculturales: un análisis alternativo de la problemática indígena contemporánea. In: Toledo V y Alarcón-Cháires P. Editores. Tópicos bioculturales: reflexiones sobre el concepto de bioculturalidad y la defensa del patrimonio biocultural de México. Michoacán: Universidad Nacional Autónoma de México, p.7-33.

MacNeish, R.S., and A. García. 1972. Excavations in the San Marco Locality in the travertine slopes. In Robert Peabody Foundation, 137-160. University of Texas Press: Published. The prehistory of the Tehuacan Valley. Texas.

May, M.P., and F.I. Ciocchini. 2018. Crisis alimentaria global, posibles salidas locales: Cultivos tradicionales, en La Plata, Argentina. Observatorio Medioambiental 21: 227-247.

Meggers, B.J. 1975. The transpacific origin of mesoamerican civilization: A preliminary review of the evidence and its theoretical implications. American Anthropologist 77: 1-27.

Narváez, A.U., T. Martínez, and M.A. Jiménez. 2016. El cultivo de maguey pulquero: opción para el desarrollo de comunidades rurales del altiplano mexicano. Revista de geografía Agrícola 56: 33-44.

Nazarea, V.D., R.E. Rhoades, and J. Andrews-Swann. 2013. Seeds of resistance, seeds of hope: Place and agency in the conservation of biodiversity. Tucson: University of Arizona Press.

Paddock, J. 1987. Cholula en Mesoamérica. Notas Mesoamericanas 10: 21-68.

Parsons, J.R., and J.A. Darling. 2000. Maguey (Agave spp.) utilization in Mesoamerican civilization: A case for Precolumbian "pastoralism”. Bol. Soc. Bot. Méx. 66: 81-91.

Payne, C.L., P. Scarborough, M. Rayner, and K. Nonaka. 2016. Are edible insects more or less "healthy" than commonly consumed meats. A comparison using two nutrient profiling models developed to combat over- and undernutrition. European Journal of Clinical Nutrition 70 (3): 285-291.

Racz, A., V. Marchesi, and I. Crnkovic. 2018. Economical, environmental and ethical impact of food wastage in hospitality and other global industries. European Journal of Bioethics 9 (1): 25-42.

Ramos-Elorduy, J., and J.M. Pino. 2001. Contenido de vitaminas de algunos insectos comestibles de México. Revista de la Sociedad Química de México 45 (2): 66-76.

Ramos-Elorduy, J., E.M. Costa, J.M. Pino, M.S. Cuevas, J. García-Figueroa, and D.H. Zetina. 2007. Conocimiento de la entomofauna útil en el poblado La Purísima Palmar de Bravo, Estado de Puebla. México. Biotemas 20 (2): 121-134.

Ramos-Elorduy, J., J.M. Moreno, A.I. Vázquez, I. Landero, H. Oliva-Rivera, and V. Camacho. 2011. Edible Lepidoptera in Mexico: Geographic distribution, ethnicity, economic and nutritional importance for rural people". Journal of Ethnobiology and Ethnomedicine 7: 2.

Reddy, G. and van Dam, R. 2020. Food, culture, and identity in multicultural societies: Insights from Singapore. Appetite. 149: 104633.

Ribeiro, J.C., B. Sousa-Pinto, J. Fonseca, S. Caldas, and L.M. Cunha. 2021. Edible insects and food safety: Allergy. Journal of Insects as Food and Feed 7 (5): 833-847.

Sahagún B. 1577. The Florentine Codex. Manuscript. Available from: https://www.wdl.org/en/item/ 10096/view/1/115/

SEDESOL. 2007. Catálogo de localidades. Unidad de Microrregiones, CIBCEC-2006. http://www.micro rregiones.gob.mx/catloc/LocdeMun.aspx?tipo $=$ clave \&campo $=1$ loc\&ent $=21 \&$ mun $=177 . \quad$ Accessed 27 February 2020.

Snijders, T. 1992. Estimation on the basic of snowball samples: How to weight. Bulletin De Méthodologie Sociologique 36: 59-70.

Toledo V. 2018. El axioma biocultural y su expresión en el espacio. In: Toledo V y Alarcón-Cháires P. Editores. Tópicos bioculturales: reflexiones sobre el concepto de bioculturalidad y la defensa del patrimonio biocultural de México. Michoacán: Universidad Nacional Autónoma de México, p. 67-76.

Toledo, V., and N. Barrera-Bassols. 2008. La memoria biocultural. La importancia ecológica de las sabidurías tradicionales. Barcelona: Icaria.

Toledo, V.M. 2006. Ecología, espiritualidad y conocimiento: De la sociedad del riesgo a la sociedad sustentable. México: Editorial Jitanjáfora/Universidad Iberoamericana/ PNUD. 
UN and FAO. 2010. The right to adequate food. Fact Sheet No. 34. Geneva: United Nations High Commissioner for Human Rights

UN. 1999. Substantive issues arising in the implementation of the international covenant on economic, social and cultural rights. General Comment 12. The right to adequate food (art. 11). E/C.12/1999/5. Economic and Social Council. United Nations. Available online: https://undocs.org/E/C.12/1999/5

UN. 2007. The United Nations Declaration on the Rights of Indigenous Peoples. 61/295. United Nations. Available online: https:/www.un.org/development/desa/indigenouspeoples/wp-content/uploads/sites/ 19/2018/11/UNDRIP_E_web.pdf

UN. 2015. Transformar nuestro mundo: la Agenda 2030 para el Desarrollo Sostenible. Resolución aprobada por la Asamblea General el 25 de septiembre de 2015. Naciones Unidas. Disponible en línea: https:// unctad.org/system/files/official-document/ares70d1_es.pdf

UN. 2020. Perspectiva crítica de los sistemas alimentarios, las crisis alimentarias y el futuro del derecho a la alimentación. Informe de la Relatora Especial sobre el derecho a la alimentación, A/HRC/43/44. Consejo de Derechos Humanos, $43^{\circ}$ Periodo de Sesiones. Naciones Unidas.

Valle, G. 2021. The past in the present: What our ancestors taught us about surviving pandemics. Food Ethics. 6: 7 .

Van Huis A., Van Itterbeeck J., Klunder H., Mertens E., Halloran A. and Muir G. 2013. Edible insects: future prospects for food and feed security. Rome (IT): Food and Agriculture Organization of the United Nations, p. 187. FAO Forestry Paper No. 171.

Vázquez, A., M.M. Aliphat, N.G. Estrella, E. Ortiz, J. Ramírez, and y Ramírez A.M. . 2016. El maguey pulquero, una planta multifuncional y polifacética: Los usos desde una visión mestiza e indígena. Scripta Ethnologica 38: 65-88.

Wassmann, B., M. Siegrist, and C. Hartmann. 2021. Correlates of the willingness to consume insects: A meta-analysis. Journal of Insects as Food and Feed 7 (5): 909-922.

Woodward, M.R. 2000. Considering household food security and diet at the classic period Village of Cerén, El Salvador (A.D. 600). Mayab 13: 22-33.

Wu, G., J. Fanzo, D.D. Miller, P. Pingali, M. Post, J.L. Steiner, and A.E. Thalacker-Mercer. 2014. Production and supply of high-quality food protein for human consumption: Sustainability, challenges, and innovations. Annals of the New York Academy of Sciences 1321 (1): 1-19.

Publisher's Note Springer Nature remains neutral with regard to jurisdictional claims in published maps and institutional affiliations. 